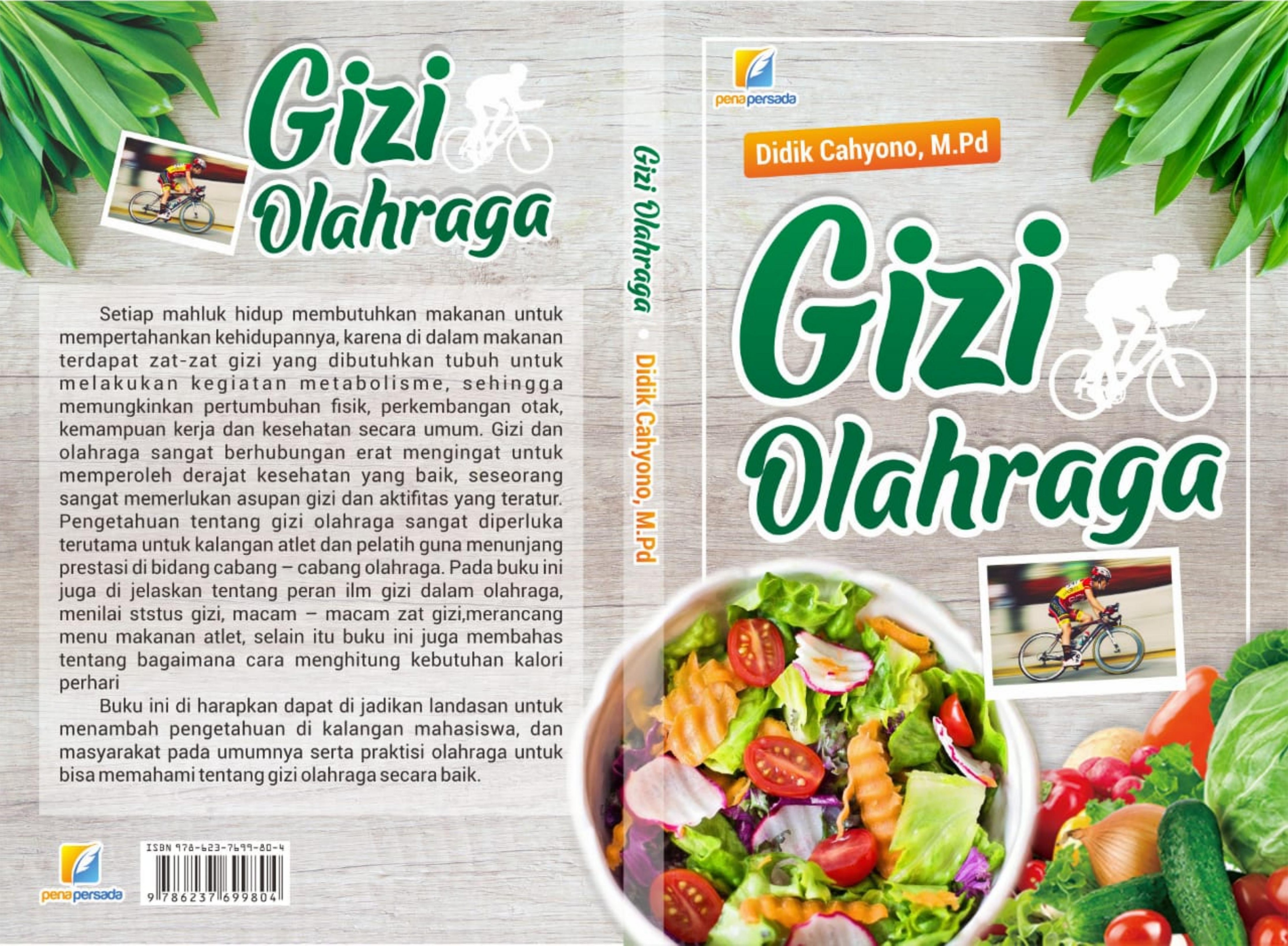




\section{GIZI OLAHRAGA}

Didik Cahyono, M.Pd.

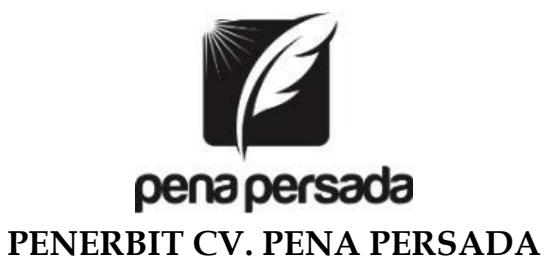




\title{
GIZI OLAHRAGA
}

\author{
Penulis : \\ Didik Cahyono, M.Pd. \\ ISBN : 978-623-7699-80-4
}

Design Cover :

Retnani Nur Briliant

Layout :

Nisa Falahia

Penerbit CV. Pena Persada

Redaksi :

Jl. Gerilya No. 292 Purwokerto Selatan, Kab. Banyumas

Jawa Tengah

Email : penerbit.penapersada@gmail.com

Website : penapersada.com

Phone : (0281) 7771388

Anggota IKAPI

All right reserved

Cetakan pertama : 2020

Hak cipta dilindungi oleh undang-undang. Dilarang memperbanyak karya tulis ini dalam bentuk apapun tanpa ijin penerbit. 


\section{KATA PENGANTAR}

Puji syukur kami panjatkan ke hadirat Tuhan Yang Maha Esa karena atas rahmat dan karunia-Nya kami bisa menyelesaikan buku "Gizi Olahraga" Untuk mahasiswa Pendidikan jasmani Fakultas keguruan dan Ilmu Pendidikan Universitas Mulawarman Kalimantan Timur.

Buku ini dibuat dengan mempertimbangkan masih kurangnya bahan ajar yang dimiliki mahasiswa pada mata kuliah ilmu gizi olahraga. Kesuksesan belajar berawal dari kemauan dan ditunjang oleh berbagai sarana, salah satu diantaranya adalah buku. Harapan kami, buku ini dapat membantu mahasiswa untuk memahami pentingnya ilmu gizi dan memahami kebutuhan gizi tentang dirinya sendiri, keluarga, lingkungan, dan masyarakat

Akhir kata penulis mengucapkan terima kasih kepada semua pihak yang telah membantu dalam menerbitan buku ini. Kritik dan saran sangat kami harapkan untuk perbaikan buku ini di masa yang akan datang.

Samarinda, Mei 2020

Penulis 


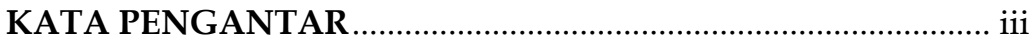

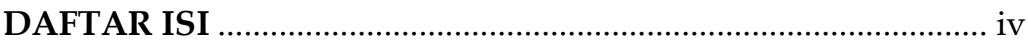

BAB I PERAN ILMU GIZI OLAHRAGA......................................... 1

BAB II MACAM-MACAM ZAT GIZI

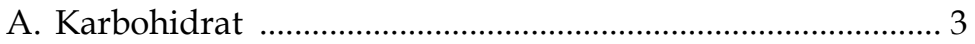

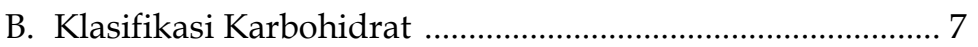

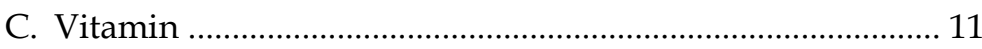

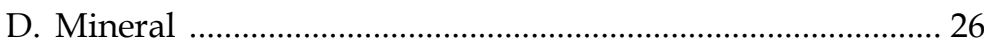

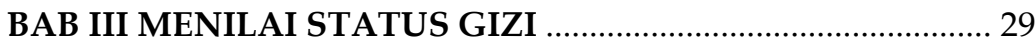

BAB IV MENGHITUNG KEBUTUHAN ENERGI

A. Cara Menghitung Kebutuhan Kalori per Hari ...................... 35

B. Cara Menghitung Kebutuhan Energi Atlet .......................... 42

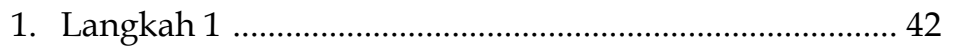

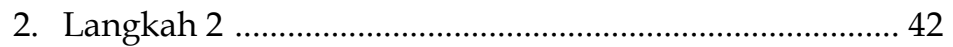

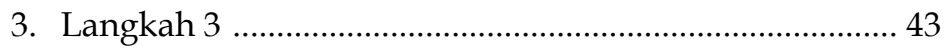

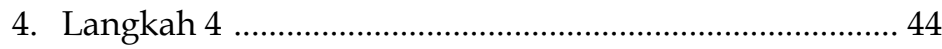

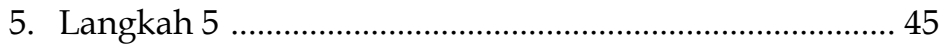

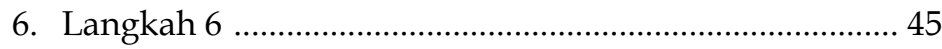

BAB V MERANCANG MENU MAKANAN ATLET

A. Menu Makanan Sehat Untuk Atlet ......................................... 46

B. Pola Makan Sehat Untuk Atlet ..................................................... 48

C. Delapan Jenis Makanan Shat Paling Direkomendasikan

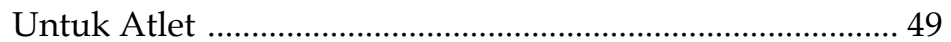

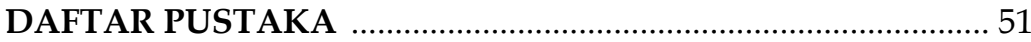

DAFTAR RIWAYAT HIDUP 


\section{BAB I \\ PERAN ILMU GIZI OLAHRAGA}

Setiap mahluk hidup membutuhkan makanan untuk mempertahankan kehidupannya, karena di dalam makanan terdapat zat-zat gizi yang dibutuhkan tubuh untuk melakukan kegiatan metabolisme, sehingga memungkinkan pertumbuhan fisik, perkembangan otak, kemampuan kerja dan kesehatan secara umum. Zat gizi adalah ikatan kimia yang diperlukan tubuh untuk melakukan fungsinya. Zat-zat tersebut digolongkan menjadi makronutrien yang meliputi karbohidrat, lemak, dan protein serta mikronutrien yang meliputi mineral dan vitamin.

Istilah gizi dan ilmu gizi di Indonesia baru mulai dikenal sekitar tahun 1952-1955. WHO mengartikan ilmu gizi sebagai ilmu yang mempelajari proses yang terjadi pada organisme hidup untuk mengambil makanan dan mengolah zat-zat padat dan cair dari makanan yang diperlukan untuk memelihara kehidupan, pertumbuhan, berfungsinya organ tubuh dan menghasilkan energi. Sementara itu Riyadi mengatakan ilmu gizi adalah cabang ilmu yang mempelajari hubungan antara makanan yang dimakan dengan kesehatan tubuh yang diakibatkannya serta faktor-faktor yang mempengaruhinya. Salah satu cabang ilmu gizi adalah gizi manusia, yang khusus mempelajari gizi pada manusia. Bagian dari gizi manusia yaitu gizi olahraga.

Ilmu Gizi dan Ilmu Gizi Olahraga :ilmu gizi adalah ilmu yang mempelajari tentang hubungan makanan dan minuman terhadap kesehatan tubuh manusia agar tidak mengalami penyakit gangguan gizi, dimana gangguan gizi sendiri adalah sebuah penyakit yang diakibatkan oleh kurangnya zat-zat vitamin tertentu sehingga mengakibatkan tubuh kita mengalami gangguan gizi. Ilmu Gizi (Nutrience Science) adalah ilmu yang mempelajari segala sesuatu tentang makanan dalam hubungannya dengan kesehatan optimal/ tubuh.[1] Sayangnya makanan sekarang bisa dibilang hampir sedikit sekali gizi yang dikandungnya. 


\section{Contohnya:}

banyak sekali penggunaan bahan kimia seperti pestisida pada sayur - sayuran biarpun proses penanamannya organik tapi tidak luput dari yang namanya pestisida, sedangkan untuk buah - buahan sekarang serba import, buah yang diimport membutuhkan kurang lebih 1 bulan dalam proses distribusinya itu menyebabkan kandungan gizi dalam buah - buahan juga berkurang. ilmu yang mempelajari hubungan antara pengelolaan makanan dengan kinerja fisik yang bermanfaat untuk kesehatan, kebugaran, pertumbuhananak serta pembinaan prestasi olahraga.

Penelitian di bidang nutrisi mempelajari hubungan antara makanan dan minuman terhadap kesehatan dan penyakit, khususnya dalam menentukan diet yang optimal. Pada masa lalu, penelitian mengenai nutrisi hanya terbatas pada pencegahan penyakit kurang gizi dan menentukan standard kebutuhan dasar nutrisi pada makhluk hidup. Angka kebutuhan nutrisi (zat gizi) dasar ini dikenal di dunia internasional dengan istilah Recommended Daily Allowance (RDA). Seiring dengan perkembangan ilmiah di bidang medis dan biologi molekular, bukti-bukti medis menunjukkan bahwa RDA belum mencukupi untuk menjaga fungsi optimal tubuh dan mencegah atau membantu penanganan penyakit kronis. Bukti-bukti medis menunjukkan bahwa akar dari banyak penyakit kronis adalah stres oksidatif yang disebabkan oleh berlebihnya radikal bebas di dalam tubuh. Penggunaan nutrisi dalam level yang optimal, dikenal dengan Optimal Daily Allowance (ODA), terbukti dapat mencegah dan menangani stres oksidatif sehingga membantu pencegahan penyakit kronis. Level optimal ini dapat dicapai bila jumlah dan komposisi nutrisi yang digunakan tepat. Dalam penanganan penyakit, penggunaan nutrisi sebagai pengobatan komplementer dapat membantu efektifitas dari pengobatan dan pada saat yang bersamaan mengatasi efek samping dari pengobatan. Karena itu, nutrisi / gizi sangat erat kaitannya dengan kesehatan yang optimal dan peningkatan kualitas hidup. Hasil ukur bisa dilakukan dengan metode antropometri. 


\section{BAB II \\ MACAM - MACAM ZAT GIZI}

\section{A. Karbohidrat}

Karbohidrat ('hidrat dari karbon', hidrat arang) atau sakarida (dari bahasa Yunani oákxapov, sákcharon, berarti "gula") adalah segolongan besar senyawa organik yang paling melimpah di bumi. Karbohidrat memiliki berbagai fungsi dalam tubuh makhluk hidup, terutama sebagai bahan bakar (misalnya glukosa), cadangan makanan (misalnya pati pada tumbuhan dan glikogen pada hewan), dan materi pembangun (misalnya selulosa pada tumbuhan, kitin pada hewan dan jamur).[1] Pada proses fotosintesis, tetumbuhan hijau mengubah karbon dioksida menjadi karbohidrat.

Secara biokimia, karbohidrat adalah polihidroksilaldehida atau polihidroksil-keton, atau senyawa yang menghasilkan senyawa-senyawa ini bila dihidrolisis.[2] Karbohidrat mengandung gugus fungsi karbonil (sebagai aldehida atau keton) dan banyak gugus hidroksil. Pada awalnya, istilah karbohidrat digunakan untuk golongan senyawa yang mempunyai rumus $(\mathrm{CH} 2 \mathrm{O}) \mathrm{n}$, yaitu senyawasenyawa yang $\mathrm{n}$ atom karbonnya tampak terhidrasi oleh $\mathrm{n}$ molekul air.[3] Namun demikian, terdapat pula karbohidrat yang tidak memiliki rumus demikian dan ada pula yang mengandung nitrogen, fosforus, atau sulfur.[2]

Bentuk molekul karbohidrat paling sederhana terdiri dari satu molekul gula sederhana yang disebut monosakarida, misalnya glukosa, galaktosa, dan fruktosa. Banyak karbohidrat merupakan polimer yang tersusun dari molekul gula yang terangkai menjadi rantai yang panjang serta dapat pula bercabang-cabang, disebut polisakarida, misalnya pati, kitin, dan selulosa. Selain monosakarida dan polisakarida, terdapat pula disakarida (rangkaian dua monosakarida) dan oligosakarida (rangkaian beberapa monosakarida). 
Peran dalam biosfer Fotosintesis menyediakan makanan bagi hampir seluruh kehidupan di bumi, baik secara langsung atau tidak langsung. Organisme autotrof seperti tumbuhan hijau, bakteri, dan alga fotosintetik memanfaatkan hasil fotosintesis secara langsung. Sementara itu, hampir semua organisme heterotrof, termasuk manusia, benar-benar bergantung pada organisme autotrof untuk mendapatkan makanan.[4] Pada proses fotosintesis, karbon dioksida diubah menjadi karbohidrat yang kemudian dapat digunakan untuk mensintesis materi organik lainnya. Karbohidrat yang dihasilkan oleh fotosintesis ialah gula berkarbon tiga yang dinamai gliseraldehida 3-fosfat.menurut rozison (2009) Senyawa ini merupakan bahan dasar senyawa-senyawa lain yang digunakan langsung oleh organisme autotrof, misalnya glukosa, selulosa, dan amilum.

1. Peran sebagai bahan bakar dan nutrisi

Kentang merupakan salah satu bahan makanan yang mengandung banyak karbohidrat. Karbohidrat menyediakan kebutuhan dasar yang diperlukan tubuh makhluk hidup. Monosakarida, khususnya glukosa, merupakan nutrien utama sel. Misalnya, pada vertebrata, glukosa mengalir dalam aliran darah sehingga tersedia bagi seluruh sel tubuh. Sel-sel tubuh tersebut menyerap glukosa dan mengambil tenaga yang tersimpan di dalam molekul tersebut pada proses respirasi seluler untuk menjalankan sel-sel tubuh. Selain itu, kerangka karbon monosakarida juga berfungsi sebagai bahan baku untuk sintesis jenis molekul organik kecil lainnya, termasuk asam amino dan asam lemak.[1] Sebagai nutrisi untuk manusia, 1 gram karbohidrat memiliki nilai energi 4 Kalori.[5] Dalam menu makanan orang Asia Tenggara termasuk Indonesia, umumnya kandungan karbohidrat cukup tinggi, yaitu antara $70-80 \%$. Bahan makanan sumber karbohidrat ini misalnya padi-padian atau serealia (gandum dan beras), umbi-umbian (kentang, singkong, ubi jalar), dan gula.[6] 
Namun demikian, daya cerna tubuh manusia terhadap karbohidrat bermacam-macam bergantung pada sumbernya, yaitu bervariasi antara 90\%-98\%. Serat menurunkan daya cerna karbohidrat menjadi 85\%.[7] Manusia tidak dapat mencerna selulosa sehingga serat selulosa yang dikonsumsi manusia hanya lewat melalui saluran pencernaan dan keluar bersama feses. Serat-serat selulosa mengikis dinding saluran pencernaan dan merangsangnya mengeluarkan lendir yang membantu makanan melewati saluran pencernaan dengan lancar sehingga selulosa disebut sebagai bagian penting dalam menu makanan yang sehat. Contoh makanan yang sangat kaya akan serat selulosa ialah buah-buahan segar, sayursayuran, dan biji-bijian.[8] Selain sebagai sumber energi, karbohidrat juga berfungsi untuk menjaga keseimbangan asam basa di dalam tubuh[rujukan?], berperan penting dalam proses metabolisme dalam tubuh, dan pembentuk struktur sel dengan mengikat protein dan lemak.

2. Peran sebagai cadangan energi

Beberapa jenis polisakarida berfungsi sebagai materi simpanan atau cadangan, yang nantinya akan dihidrolisis untuk menyediakan gula bagi sel ketika diperlukan. Pati merupakan suatu polisakarida simpanan pada tumbuhan. Tumbuhan menumpuk pati sebagai granul atau butiran di dalam organel plastid, termasuk kloroplas. Dengan mensintesis pati, tumbuhan dapat menimbun kelebihan glukosa. Glukosa merupakan bahan bakar sel yang utama, sehingga pati merupakan energi cadangan.[9] Sementara itu, hewan menyimpan polisakarida yang disebut glikogen. Manusia dan vertebrata lainnya menyimpan glikogen terutama dalam sel hati dan otot. Penguraian glikogen pada sel-sel ini akan melepaskan glukosa ketika kebutuhan gula meningkat. Namun demikian, glikogen tidak dapat diandalkan sebagai sumber energi hewan untuk jangka waktu lama. Glikogen simpanan akan terkuras habis hanya 
dalam waktu sehari kecuali kalau dipulihkan kembali dengan mengonsumsi makanan.[9]

3. Peran sebagai materi pembangun

Organisme membangun materi-materi kuat dari polisakarida struktural. Misalnya, selulosa ialah komponen utama dinding sel tumbuhan. Selulosa bersifat seperti serabut, liat, tidak larut di dalam air, dan ditemukan terutama pada tangkai, batang, dahan, dan semua bagian berkayu dari jaringan tumbuhan.[10] Kayu terutama terbuat dari selulosa dan polisakarida lain, misalnya hemiselulosa dan pektin. Sementara itu, kapas terbuat hampir seluruhnya dari selulosa.

Polisakarida struktural penting lainnya ialah kitin, karbohidrat yang menyusun kerangka luar (eksoskeleton) arthropoda (serangga, laba-laba, crustacea, dan hewanhewan lain sejenis). Kitin murni mirip seperti kulit, tetapi akan mengeras ketika dilapisi kalsium karbonat. Kitin juga ditemukan pada dinding sel berbagai jenis fungi.[8] Sementara itu, dinding sel bakteri terbuat dari struktur gabungan karbohidrat polisakarida dengan peptida, disebut peptidoglikan. Dinding sel ini membentuk suatu kulit kaku dan berpori membungkus sel yang memberi perlindungan fisik bagi membran sel yang lunak dan sitoplasma di dalam sel.[11] Karbohidrat struktural lainnya yang juga merupakan molekul gabungan karbohidrat dengan molekul lain ialah proteoglikan, glikoprotein, dan glikolipid.

Proteoglikan maupun glikoprotein terdiri atas karbohidrat dan protein, namun proteoglikan terdiri terutama atas karbohidrat, sedangkan glikoprotein terdiri terutama atas protein. Proteoglikan ditemukan misalnya pada perekat antarsel pada jaringan, tulang rawan, dan cairan sinovial yang melicinkan sendi otot. Sementara itu, glikoprotein dan glikolipid (gabungan karbohidrat dan lipid) banyak ditemukan pada permukaan sel hewan.[12] Karbohidrat pada glikoprotein umumnya berupa oligosakarida dan dapat berfungsi sebagai penanda sel. 
Misalnya, empat golongan darah manusia pada sistem ABO $(\mathrm{A}, \mathrm{B}, \mathrm{AB}$, dan $\mathrm{O}$ ) mencerminkan keragaman oligosakarida pada permukaan sel darah merah.[13]

\section{B. Klasifikasi Karbohidrat}

1. Monosakarida

Monosakarida merupakan karbohidrat paling sederhana karena molekulnya hanya terdiri atas beberapa atom $\mathrm{C}$ dan tidak dapat diuraikan dengan cara hidrolisis menjadi karbohidrat lain. Monosakarida dibedakan menjadi aldosa dan ketosa. Contoh dari aldosa yaitu glukosa dan galaktosa. Contoh ketosa yaitu fruktosa.

2. Disakarida dan oligosakarida

Disakarida merupakan karbohidrat yang terbentuk dari dua molekul monosakarida yang berikatan melalui gugus -OH dengan melepaskan molekul air. Contoh dari disakarida adalah sukrosa, laktosa, dan maltosa.

3. Polisakarida

Polisakarida merupakan karbohidrat yang terbentuk dari banyak sakarida sebagai monomernya. Rumus umum polisakarida yaitu $\mathrm{C} 6(\mathrm{H} 10 \mathrm{O} 5) n$. Contoh polisakarida adalah selulosa, glikogen, dan amilum.

4. Protein

Protein (asal kata protos dari bahasa Yunani yang berarti "yang paling utama") adalah senyawa organik kompleks berbobot molekul tinggi yang merupakan polimer dari monomer-monomer asam amino yang dihubungkan satu sama lain dengan ikatan peptida. Molekul protein mengandung karbon, hidrogen, oksigen, nitrogen dan kadang kala sulfur serta fosfor. Protein berperan penting dalam struktur dan fungsi semua sel makhluk hidup dan virus.

Kebanyakan protein merupakan enzim atau subunit enzim. Jenis protein lain berperan dalam fungsi struktural atau mekanis, seperti misalnya protein yang membentuk batang dan sendi sitoskeleton. Protein terlibat dalam sistem 
kekebalan (imun) sebagai antibodi, sistem kendali dalam bentuk hormon, sebagai komponen penyimpanan (dalam biji) dan juga dalam transportasi hara. Sebagai salah satu sumber gizi, protein berperan sebagai sumber asam amino bagi organisme yang tidak mampu membentuk asam amino tersebut (heterotrof).

Protein merupakan salah satu dari biomolekul raksasa, selain polisakarida, lipid, dan polinukleotida, yang merupakan penyusun utama makhluk hidup. Selain itu, protein merupakan salah satu molekul yang paling banyak diteliti dalam biokimia. Protein ditemukan oleh Jöns Jakob Berzelius pada tahun 1838.

Biosintesis protein alami sama dengan ekspresi genetik. Kode genetik yang dibawa DNA ditranskripsi menjadi RNA, yang berperan sebagai cetakan bagi translasi yang dilakukan ribosom.[1] Sampai tahap ini, protein masih "mentah", hanya tersusun dari asam amino proteinogenik. Melalui mekanisme pascatranslasi, terbentuklah protein yang memiliki fungsi penuh secara biologi.[2][3]

a. Struktur

Struktur tersier protein. Protein ini memiliki banyak struktur sekunder beta-sheet dan alpha-helix yang sangat pendek. Model dibuat dengan menggunakan koordinat dari Bank Data Protein (nomor 1EDH).

Struktur protein dapat dilihat sebagai hirarki, yaitu berupa struktur primer (tingkat satu), sekunder (tingkat dua), tersier (tingkat tiga), dan kuartener (tingkat empat):[4][5] struktur primer protein merupakan urutan asam amino penyusun protein yang dihubungkan melalui ikatan peptida (amida). Frederick Sanger merupakan ilmuwan yang berjasa dengan temuan metode penentuan deret asam amino pada protein, dengan penggunaan beberapa enzim protease yang mengiris ikatan antara asam amino tertentu, menjadi fragmen peptida yang lebih pendek untuk dipisahkan 
lebih lanjut dengan bantuan kertas kromatografik. Urutan asam amino menentukan fungsi protein, pada tahun 1957, Vernon Ingram menemukan bahwa translokasi asam amino akan mengubah fungsi protein, dan lebih lanjut memicu mutasi genetik. struktur sekunder protein adalah struktur tiga dimensi lokal dari berbagai rangkaian asam amino pada protein yang distabilkan oleh ikatan hidrogen. Berbagai bentuk struktur sekunder misalnya ialah sebagai berikut: alpha helix ( $\alpha$-helix, "puntiran-alfa"), berupa pilinan rantai asam-asam amino berbentuk seperti spiral; beta-sheet ( $\beta$ sheet, "lempeng-beta"), berupa lembaran-lembaran lebar yang tersusun dari sejumlah rantai asam amino yang saling terikat melalui ikatan hidrogen atau ikatan tiol (S$\mathrm{H})$; beta-turn, ( $\beta$-turn, "lekukan-beta"); dan gamma-turn, ( $\gamma$-turn, "lekukan-gamma").[4] struktur tersier yang merupakan gabungan dari aneka ragam dari struktur sekunder. Struktur tersier biasanya berupa gumpalan. Beberapa molekul protein dapat berinteraksi secara fisik tanpa ikatan kovalen membentuk oligomer yang stabil (misalnya dimer, trimer, atau kuartomer) dan membentuk struktur kuartener. contoh struktur kuartener yang terkenal adalah enzim Rubisco dan insulin.

Struktur primer protein bisa ditentukan dengan beberapa metode: (1) hidrolisis protein dengan asam kuat (misalnya, $6 \mathrm{~N} \mathrm{HCl}$ ) dan kemudian komposisi asam amino ditentukan dengan instrumen amino acid analyzer, (2) analisis sekuens dari ujung- $\mathrm{N}$ dengan menggunakan degradasi Edman, (3) kombinasi dari digesti dengan tripsin dan spektrometri massa, dan (4) penentuan massa molekular dengan spektrometri massa. Struktur sekunder bisa ditentukan dengan menggunakan spektroskopi circular dichroism (CD) dan Fourier Transform Infra Red (FTIR).[6] Spektrum CD dari puntiran-alfa menunjukkan dua absorbans negatif pada 
208 dan $220 \mathrm{~nm}$ dan lempeng-beta menunjukkan satu puncak negatif sekitar 210-216 nm. Estimasi dari komposisi struktur sekunder dari protein bisa dikalkulasi dari spektrum CD. Pada spektrum FTIR, pita amida-I dari puntiran-alfa berbeda dibandingkan dengan pita amida-I dari lempeng-beta. Jadi, komposisi struktur sekunder dari protein juga bisa diestimasi dari spektrum inframerah.

Struktur protein lainnya yang juga dikenal adalah domain. Struktur ini terdiri dari 40-350 asam amino. Protein sederhana umumnya hanya memiliki satu domain. Pada protein yang lebih kompleks, ada beberapa domain yang terlibat di dalamnya. Hubungan rantai polipeptida yang berperan di dalamnya akan menimbulkan sebuah fungsi baru berbeda dengan komponen penyusunnya. Bila struktur domain pada struktur kompleks ini berpisah, maka fungsi biologis masing-masing komponen domain penyusunnya tidak hilang. Inilah yang membedakan struktur domain dengan struktur kuartener. Pada struktur kuartener, setelah struktur kompleksnya berpisah, protein tersebut tidak fungsional.

b. Kekurangan Protein

Protein sendiri mempunyai banyak sekali fungsi di tubuh kita. Pada dasarnya protein menunjang keberadaan setiap sel tubuh, proses kekebalan tubuh. Setiap orang dewasa harus sedikitnya mengonsumsi $1 \mathrm{~g}$ protein per $\mathrm{kg}$ berat tubuhnya. Kebutuhan akan protein bertambah pada perempuan yang mengandung dan atlet-atlet. Kekurangan Protein bisa berakibat fatal: Kerontokan rambut (Rambut terdiri dari $97-100 \%$ dari Protein -Keratin) Yang paling buruk ada yang disebut dengan Kwasiorkor, penyakit kekurangan protein.[7] Biasanya pada anak-anak kecil yang menderitanya, dapat dilihat dari yang namanya busung lapar, yang disebabkan oleh filtrasi air di dalam pembuluh darah 